\title{
Knowledge and Perception of Issues of Climate Change in Awka South Local Government Area of Anambra State, Nigeria \\ DOI: $10.36108 / \mathrm{NJSA} / 4102 / 12(0270)$
}

\author{
Ngozi G. Egbue \\ Ignatius U. Nwankwo \\ Tochukwu V. Anayo \\ Department of Sociology/Anthropology \\ Nnamdi Azikiwe University, Awka \\ Anambra State, Nigeria
}

\begin{abstract}
The study investigated the perception and extent to which the people of Awka South local government area are knowledgeable about climate change and related issues. Two hundred and seven respondents were drawn using a combination of multi-stage and simple random sampling techniques. Statistical analysis was accomplished by the use of descriptive and inferential statistics. Two hypotheses were formulated and tested using chi-square statistics. The findings reveal that there is a low level of knowledge of climate change in the study area despite relatively high level of education in the area. There is also a significant relationship between level of education and knowledge of climate change, whereas there is no relationship between occupation of respondents and knowledge of socio-economic effects of climate change. It is recommended that public enlightenment/ sensitization on climate change should be initiated given the environmental devastation consequent upon it. There is also need to enrich geography and social studies curricula for schools in the area with current issues such as climate change to broaden their knowledge and ensure that high level of education ultimately leads to improved knowledge/awareness of climate change and its consequences.
\end{abstract}

Keywords: climate change, global warming, environmental condition, agricultural activities, public enlightenment

\section{Introduction}

One of the greatest environmental challenges that confront humanity today is the issue of climate change. Over the years, there have been changes in weather condition, mean annual temperature, sea level, precipitation and other aspects of climate across the globe. For instance, Wight (2005) notes that since 1855, global average temperature has shown periods of cooling and warming but in general has increased by $0.6^{\circ} \mathrm{C}$ annually. Similarly, Odjugo (2010) asserts that extreme violent weather has occurred throughout history. He further contended that climate conditions of the ice age, characterized by very cold and relatively harsh climate, which man's ancestors battled with has remarkably changed today with upsurge in climate related hazards like global warming and other forms of climate change. 
The Inter-governmental Panel on Climate Change (IPCC, 2007) defines climate change as alterations or modifications in the state of the climate that can be indentified (e.g. using statistical tests). It includes increases in global average air and ocean temperatures as well as changes in the mean and/ or the variability of climate properties which persist for an extended period, typically decades or longer. The IPCC (2007) further observed that annual global mean temperature is projected to increase from approximately one to more than six degrees centigrade by the end of the $21^{\text {st }}$ century.

Indeed, climate change is an evidence of the fact that alteration is the constant rule of the physical environment especially with the presence of human beings and their distorting impacts on their environments. Although the length of time it takes for change in climate to manifest matters, the level of deviations from the normal and its impacts on the ecology are most paramount.

Odjugo (2010) clarifies that climate change is different from situations of mere climate fluctuations or climate variability which denote inherent dynamic nature of climate on various temporal scales. For him, a change in climate usually takes place over a long period of time of at least 150 years, with clear and permanent impacts on the ecosystem. Further, he contended that climate change is induced by two basic factors which include natural process (termed biogeographic) and human activities (termed anthropogenic) (Odjugo, 2010). According to him, the natural processes are the astronomical and the extraterrestrial factors which include changes in the eccentricity of the earth's orbit, changes in solar radiation quantity and quality among others. On the other hand, Odjugo maintained that the anthropogenic factors involve human activities that either emit large amount of greenhouse gases into the atmosphere that depletes the ozone layer and/ or warm the earth. It also includes all activities of man that reduce the amount of carbons absorbed from the atmosphere.

On his part, and in support of the anthropogenic viewpoint of climate change, Fellmann (2002) argued that humankind's massive assault on the atmosphere presumably began with the industrial revolutions of the $18^{\text {th }}$ century. Enger and Smith (2002) noted that burning of coal, oil and natural gas to heat our homes, power our cars, the use of generators and other forms of illumination of cities produce carbon-dioxides and other gases as by-products. Deforestation and clearing of land due to urbanization and agricultural practice also reduces the amount of carbon sinks.

Joseph Blast (2010) in his 'seven theories of climate change' developed seven possible causes of climate change which encompasses both the natural and the anthropogenic processes advanced by Odjugo (2010). The first cause of climate change according to Blast (2010) is anthropogenic global warming where he argued that human emission of greenhouse gases (principally carbon dioxide, methane and CFC) are causing a catastrophic rise in global temperature. According to him, when concentrations of atmospheric 
greenhouse gases rise, the greenhouse effect is intensified and much warmer temperature is produced. In relation to this, Giddens (2006), observed that since the start of industrialization, the concentration of greenhouse gases has risen significantly with human activities such as burning of solid waste and fossil fuel (oil, natural gas and coal) to heat our homes, power our cars , generate and illuminate cities and other activities that emit these gases into the atmosphere.

The second cause, Blast (2010) argues, is as a result negative feedbacks from biological and chemical processes which entirely upset whatever positive feedbacks might be caused by rising carbon dioxide and thus alter the climate. The third postulation is that changes in the formation of clouds create negative feedback that cancel out or nearly all of the warming effect of higher level of carbon dioxide. Fourthly, Blast held that mankind's greatest influence on climate is not its emission of greenhouse gases but its transformation of the earth's surface through desert irrigation, deforestation, and clearing of land for agricultural and industrial undertakings which reduce the amount of carbon dioxide sinks.

Blast contends that global temperature variations were due to the slowdown of the oceanic thermo line circulation. This he associated as the fifth cause of climate change. The sixth, he argues is that most or all of the warming of the latter part of the twentieth century can be explained by natural gravitational and magnetic oscillation of the solar system induced by the planets movement through space. The seventh cause as advanced by Blast is that solar variability accounts for most or all the warming in the late $20^{\text {th }}$ century and will dominate climate in the $21^{\text {st }}$ century regardless of man-made greenhouse gases emission.

However, despite the possible causes of climate change as advocated by Blast, the IPCC still holds that the greatest influence on the earth's climate is the activities of mankind which has speeded up the process of climate change. Man also encounters several of the problems arising from climate change.

\section{The Problems}

Against the above background, it could be concluded that climate change, irrespective of manner of conceptualization, propels a lot of environmental problems that impacts on both the physical surroundings and the people. Although a small increase in average temperature of earth may be seen as trivial, this increase could set in motion changes that could significantly alter the climate of regions of the world including Africa, giving rise to cases of flooding, desertification and gully erosion, etc. Furthermore, climate change though essentially a bio-physical phenomenon has rich sociological perspectives because it is strongly linked to ways of life or activities (culture) of social groups. Its effects are also substantial on such social groups, impacting on all aspects of human existence such as agriculture, security, tourism, transportation, etc. 
Awka South Local Government Area (LGA) of Anambra State, located in the southeast geo-political zone of Nigeria, is made up of nine agrarian communities. The LGA depends mostly on natural environment for livelihood. Unfortunately, such natural environment suitable for agricultural activities is affected by climate change. The continuous change in climatic conditions distorts planning for agriculture and adversely affects food production. There is substantial destruction of the natural environment thus creating more poverty in the area, as their source of livelihood is under threat. Also, there is climate change induced problems like gully erosion ravaging the land areas of AwkaSouth. This has left some residents homeless and destroyed farmlands.

Accurate information and knowledge about climate change does not seem widespread in Awka-South. Consequently, many people ignorantly engage in activities that increase climate change and make the area more vulnerable to its impacts. The impacts of climate change which are already evident in the area demand adaptive and mitigating strategies to tackle them. Unfortunately, strategies are not adequately circulated in the area by applicable government agencies leaving the people to resort to traditional methods of dealing with harsh weather induced problems. Prominent in such traditional methods are prayers and sacrifices to gods and ancestors.

The health of the population of Awka-South is also under threat because climate change increases the incidence of diseases via extension of geographical area characteristics and nature and length of the seasons thus favouring disease vectors such as mosquitoes. It is also possible for cases of skin cancer and other diseases caused by extreme heat waves to become rampant in the area as the depletion of ozone layers has made radiations from the sun to directly hit the earth.

Because of aforementioned problems associated with climate change in the study area, there is immense need for dissemination of new and reliable information/knowledge about the phenomenon as a catalyst for sustainable development in the area. The local government authority ought to be at the forefront of such information dissemination drive on climate change, bearing in mind that perception (an idea, a belief or an image possessed as a result of how things are seen or understood), knowledge (information, understanding and skills grained through education or experience) and attitudinal change are central issues that shape the nature of man's response to climate change.

Against this backdrop, the current paper examined the nature of perception and knowledge of climate change in Awka South LGA of Anambra state, visà-vis government's response towards tackling the problem of climate change. Of particular interest is to examine government's effort toward positively affecting the nature of perception and the knowledge base of residents of Awka-South about climate change for sustainable development.

The study was guided by the following research questions: What are the perceived forms of climate change which residents of Awka South LGA 
experience in their communities? How do the people of Awka-South view changes in climatic conditions in terms of their causes? What are the perceived effects of climate change on socio-cultural activities in the area? To what extent are the people of Awka-South knowledgeable about issues related to climate change? To what extent have leadership/governance at Awka South LGA made efforts at enhancing climate change awareness to ensure sustained development of the area? What measures could be taken to further enhance knowledge and understanding of climate change in the area?

The objectives of this study are derived from the research question raised above: explore the perceived forms of climate change which residents of Awka South LGA experience; investigate how the people of Awka South LGA view the changes in climate condition in terms of causes; investigate the perceived effects of climate change on socio-cultural activities in the area; determine the extent to which the people of Awka South LGA are knowledgeable about issues related to climate change; examine leadership/ governance efforts at enhancing climate change awareness to ensure steady development in Awka South LGA; and appraise measures to be taken to enhance knowledge and understanding of climate change in the area.

Two hypotheses guide this work, namely:

1. There is a significant relationship between level of educational attainment and knowledge of climate change.

2. There is a significant relationship between occupation and perception of the socio-economic effects of climate change in Awka LGA.

\section{Theoretical thrust}

Alfred Schultz (1899-1959) propounded the phenomenological perspective in which he sought to provide a critical foundation for Max Weber's interpretive sociology. This he sought to do by applying methods and insights derived from phenomenological philosophy of Edmund Husserl to the study of the social world. According to Haralambos and Holborn (2008), the contribution of Schultz was of two fold. First, he described and analyzed the essential structure of social world - the world we ordinarily take for granted or familiar with; second, he offered an account of the way in which subjectivity is involved in the constitution of social meaning, social action and indeed social world.

In his use of the concept of 'inter-subjectivity', Schultz argues that individual and society are mutually inclusive. Social world meaningfulness is constituted by individuals and in order to understand the social world, it becomes necessary to examine the social agent which is thus the focus of phenomenology. Inter-subjectivity which involves sharing of experience by individuals in the society constitutes the structure of meaning that make up social reality (Nnonyelu, 2009). Thus, events have no existence outside of the meanings and interpretive procedures which created them.

In relation to the subject of study, phenomenology as a theoretical standpoint aids the understanding of climate change as a socially constructed idea. It is a by-product of the people (scientists, politicians and the media) who 
have been and are involved in the way it is portrayed. The meanings and interpretations people attribute to climate change are combinations of different experiences of individuals through social interaction. They constitute the perceptions and knowledge of the members of the society which continually undergo modifications. From phenomenological perspective, knowledge and perception of climate change is culturally relative. It is defined by the different ways that individuals experience and interpret their natural environment. Thus climate change and the magnitude of its effect on any society are intricately related to the meaning individuals associate with it in that particular society. This situation is applicable to the way climate change is perceived in Awka South LGA of Anambra state of Nigeria.

\section{Methods}

The study area is Awka South L.G.A of Anambra state with a total population of 189, 654 persons (National Population Census, 2006). However, the target population constituted adults of 18 years and above who can understand the questionnaire instrument designed to gather data. The second instrument for the study is key informant interview guide. The scope of the study was limited to ascertaining the perceptions and extent to which people are knowledgeable about issues of climate change, in terms of causes, forms and impacts of climate change on the society. The study also explored leadership/governance efforts at enhancing climate change awareness to ensure steady development.

A sample size of 220 study participants' selected through multi-stage sampling technique responded to the questionnaire. The multi-stage process incorporated the cluster and the simple random techniques. In this regard, the eight communities of Awka South L.G.A were clustered into two using both proximity and north-south divide as yardsticks. This method generated four communities in each cluster. Then using a simple random sampling method, Awka and Mbaukwu communities were selected from each cluster. Villages in the two selected communities where listed and Amaikwo and Namkpu were selected through simple random respectively. In both Namkpu village of Mbankwu and Amaikwo village at Awka, the researcher and assistants identified major routes/ streets and numbered the compounds thereto. A total of 55 compounds with odd numbers were selected from each village. In each compound, two respondents on whom the questionnaire was administered were selected. The respondents were selected through simple random method where all adults in each compound constituted the sampling frame. A total of 110 respondents were selected per village/community.

On the other hand, two key informants purposively drawn from the State Ministry of Environment, Awka on the basis of their expertise, and knowledge and field operations in the area of climate change were interviewed. The data collected from the various respondents were analyzed statistically through a 
simple percentages method and frequency tables. Hypotheses formulated were tested using chi-square.

\section{Findings}

The quantitative data collected was coded, entered into a computer, and processed, using a variety of statistical techniques like frequency tables, percentages and chi-square, etc. The qualitative data was extracted and reviewed before inclusion in this paper. Out of 220 questionnaires distributed, 207 were returned completely and correctly filled, giving a completion rate of 94 per cent. The quantitative analysis was based on these 207 correctly completed questionnaires.

\section{Characteristics of Respondents}

The sex distribution of respondents show that 106 (51.1\%) were males, while $101(48.8 \%)$ were females. About 35 per cent of the respondents were within age bracket of 18-24years; $40(19.3 \%)$ within the ages of 25-31years; 27 $(13.0 \%)$ within the ages of 32-38years; $20(9.7 \%)$ within the ages of 3945years; and $46(22.2 \%)$ aged 46 years and above. The mean age of respondents stood at 36.7 years.

In terms of marital status, the majority (108 or 52.2\%) of the respondents were single, whereas $79(38.2 \%)$ of them were married; $3(1.4 \%)$ were separated, and $17(8.2 \%)$ were widowed. Data on educational attainment show that $30(14.5 \%)$ of respondents had first school leaving certificate; $85(41.1 \%)$ had WAEC/NECO/SSCE; 21 (10.1\%) had NCE/OND; 63 (30.4\%) had B.Sc /HND; while $7(3.4 \%)$ had $\mathrm{PhD}$. The level of educational attainment for the area of study is quite high, which is hardly surprising given that Awka is the educational hub of Anambra State.

The analysis of religious affiliations shows that Christianity is the predominant religion in Awka South LGA. A total of 201 (97.1\%) of the respondents are Christians; $4(1.9 \%)$ of them are Africa traditional religionists, whereas $2(1.0 \%)$ are of other religions. Finally, occupational distribution of respondents show that $68(32.9 \%)$ were civil servants, $15(7.3 \%)$ were farmers, $48(23.2 \%)$ were traders, $39(18.8 \%)$ were students, while $37(17.9 \%)$ of them were unemployed applicants.

\section{Analysis of Research Questions}

Five questions that guided the research are re-stated and analyzed below.

1. Research Question 1: What are the perceived forms/types of climate change which residents of Awka South LGA experience in their area? The findings are shown in Table 1 below. 
Table 1: Distribution of Respondents by their perception of forms/types of Climate Change experienced by residents of Awka

\begin{tabular}{|l|l|l|}
\hline Responses & Frequency & Percentage \\
\hline $\begin{array}{l}\text { Heavy and longer periods of rain resulting into } \\
\text { flooding and delayed dry seasons (not coming } \\
\text { when due) }\end{array}$ & 142 & $40.3 \%$ \\
\hline Increased heat/ Rise in earth's temperature & 187 & $53.1 \%$ \\
\hline Rise in sea level & 10 & 2.8 \\
\hline Desertification/draught & 5 & 1.4 \\
\hline Soil erosion & 8 & 2.3 \\
\hline Total & $\mathbf{2 0 7}$ & $\mathbf{1 0 0 . 0}$ \\
\hline
\end{tabular}

Table 1 shows that $187(53.1 \%)$ of the respondents regarded increased heat as a major form or manifestation of climate change in their area. Another form of climate change mentioned by the $142(40.3 \%)$ respondents is heavy rains and dry seasons not coming as and when due, while $5(1.4 \%)$ of the respondents regarded desertification as a type of climate change. Data from the key informant interview corroborated the views from the quantitative data. As one of the key informants stated:

Intense heat, high precipitation, and high temperature are the common types of climate change in Awka South Local government area. (Male respondent, 53years old)

Another key informant attested that:

Flooding due to high precipitation remains one of the most common climate change manifestation in Awka South local government.

Research Question 2: How do the people of Awka South L.G.A view/perceive changes in climate condition in terms of causes? The findings are shown on Table 2 below.

Table 2: Distribution of Respondents by their opinion on causes of climate change

\begin{tabular}{|l|l|l|}
\hline Responses & Frequency & Percentage \\
\hline It is a natural process or occurrence. & 138 & 67.6 \\
\hline $\begin{array}{l}\text { Fallout of human activities and development } \\
\text { projects on earth. }\end{array}$ & 61 & 29.9 \\
\hline $\begin{array}{l}\text { Both a natural process and fallout of human } \\
\text { activities. }\end{array}$ & 5 & 2.5 \\
\hline Total & $\mathbf{2 0 7}$ & $\mathbf{1 0 0}$ \\
\hline
\end{tabular}


Table 2 shows that $138(66.7 \%)$ respondents believe climate change is a natural occurrence, $61(29.9 \%)$ of them asserted that it is as a result of human activities and development projects on earth while only $5(2.5 \%)$ of them correctly linked climate change to both a natural process and fallout of human activities/ development projects. Information from the key informant interview disagreed with that of the questionnaire. It was gathered that the major cause of climate is anthropogenic although it can be naturally induced.

One of the respondents in the key informant interview opined that:

Climate change mainly arise in response to man-made changes or activities on earth ... activities like cutting down of tress, industrialization have enhanced climate changes.

Research Question 3: What are the perceived effects of climate change on socio-economic activities in Awka South L.G.A? The findings are shown in Tables 3 and 4.

Table 3: Distribution of Respondents on by their opinion on whether climate change affects the socio-economic activities of the area

\begin{tabular}{|l|l|l|}
\hline Respondent & Frequency & Percentage \\
\hline Yes & 149 & $73.4 \%$ \\
No & 54 & $26.6 \%$ \\
Total & $\mathbf{2 0 7}$ & $\mathbf{1 0 0 . 0 \%}$ \\
\hline
\end{tabular}

Table 3 shows that $149(73.4 \%)$ respondents agreed that climate changes affects socio-economic activities while $54(26 . \%)$ of them disagreed. Data gathered from the qualitative instrument agrees that the socio-economic activities of the people are affected by climate change. Quoting one of the key informants:

People are prevented from going out due to indiscriminate rain and sun, and agricultural yields are no longer predictable and mostly declining.

Table 4: Distribution of Respondents by their opinion about what constitutes the major Socio-Economic Effect of Climate Change in South L.G.A.

\begin{tabular}{|l|l|l|}
\hline Responses & Frequency & Percentage \\
\hline Poor farm produce & 151 & $72.9 \%$ \\
\hline Loss of lives and properties & 26 & $12.6 \%$ \\
\hline $\begin{array}{l}\text { Health problems (diseases, insanitary } \\
\text { environment) }\end{array}$ & 23 & $11.1 \%$ \\
\hline Insecurity & 7 & $3.4 \%$ \\
\hline Total & $\mathbf{2 0 7}$ & $\mathbf{1 0 0 \%}$ \\
\hline
\end{tabular}


Table 4 indicate that an overwhelming majority of the respondents mentioned poor farm produce as major effect of climate change 151(72.9\%); $23(11.1 \%)$ respondents stated that climate change increases health problems, $26(12.6 \%)$ of them held that it leads to loss of lives and properties, while just $4(3.4 \%)$ associated it with insecurity. The key informant interview affirmed that agriculture remains the most affected by climate change in Awka south L.G.A. followed by health of the people being threatened by climate change and the adverse on lives and properties of the people.

Research Question 4: To what extent are the people of Awka South knowledgeable about climate change related issues? The findings are shown in tables 5 and 6 .

Table 5: Distribution of Respondents by their self-assessment of how informed or knowledgeable they are about climate change issues

\begin{tabular}{|l|l|l|}
\hline Respondent & Frequency & Percentage \\
\hline Well informed & 59 & 28.5 \\
\hline Fairly informed & 111 & 53.6 \\
\hline Not informed & 37 & 17.87 \\
\hline Total & $\mathbf{2 0 7}$ & $\mathbf{1 0 0 . 0}$ \\
\hline
\end{tabular}

Table 5 shows that the majority of the respondents (111 or 53.6\%) stated that they were fairly well informed about climate change issues. However, 59 or $28.5 \%$ of them claim to be well informed, while 37 or $17.87 \%$ of them were not informed, or had no knowledge of climate change issues. The qualitative data support the view that most residents of Awka South L.G.A were not well informed or did not have adequately knowledgeable about climate change issues.

One of the respondents emphasized that:

.... Quite a large percentage of residents of Awka South and its environs are not aware of the subject of climate change or its huge implications to human existence on earth. The people are also not aware that their activities contribute to global warming. 
Table 6: Distribution of Respondents by their Knowledge Profile on Climate Change using 4-point Criteria of Cause, Signs, Effects, and Control

\begin{tabular}{|l|l|l|}
\hline 4-Point Knowledge Criteria/ Profile & $\begin{array}{l}\text { Frequency } \\
\mathbf{n = 2 0 7}\end{array}$ & $\begin{array}{l}\text { Percentage } \\
\text { (\%) }\end{array}$ \\
\hline Cause of climate change & & \\
Germ/micro-organisms & 22 & 10.6 \\
Biogenic and human activities & 13 & 6.3 \\
Human activities on earth's surface only & 17 & 8.2 \\
Angry Gods & 87 & 42.2 \\
Don't Know & 68 & 32.9 \\
\hline Signs of climate change & & \\
Remarkable variation in seasonal attributes & 25 & 12.1 \\
Too much rain and flooding & 40 & 19.3 \\
Intense hot weather and heat & 33 & 15.9 \\
Encroaching desertification & 26 & 12.6 \\
Don't know & 80 & 38.6 \\
\hline Which is not an effect of climate change & & \\
Flooding, & 37 & 17.9 \\
Poor agricultural yield & 32 & 15.5 \\
Political instability & 45 & 21.7 \\
Don't Know & 93 & 44.9 \\
\hline Whether climate change be controlled & & \\
Yes & 47 & 22.7 \\
No & 73 & 35.3 \\
Don't know & 87 & 42.03 \\
\hline
\end{tabular}

Table 6 shows the low level of knowledge of residents of Awka South LGA about climate change given the responses of study participants to the 4-point criteria for assessing knowledge of climate change. The majority of respondents clearly stated that they do not know the signs, effects, and controls required for climate change. In respect to cause, the majority attributed the phenomena to angry gods or claimed lack of knowledge. This buttresses the fact that accurate knowledge of the causes of climate change is low in the area of study. This characteristics low level of knowledge is evident in the responses for other issues in Table 6. For instance, about 39 percent of the respondents did not know any sign of climate change; about 45 per cent did not know the effect of climate change and 18 per cent did not know that flooding results from climate change; and 42 per cent did not know whether or not climate change can be controlled.

Research Question 5: To what extent have leadership/governance at Awka South local government committed efforts at enhancing climate change awareness to ensure sustained development of the area? 
Table 7: Distribution of respondents by their opinion about commitment of leadership/ governance to climate change education in Awka South LGA

\begin{tabular}{|l|l|l|}
\hline Respondent & Frequency & Percentage \\
\hline $\begin{array}{l}\text { Leadership/governance is not committed to } \\
\text { public education on climate change } \\
\text { (awareness creation) }\end{array}$ & 152 & 73.4 \\
\hline $\begin{array}{l}\text { Climate change awareness is vigorously } \\
\text { pursued in urban and rural area by local } \\
\text { government officers }\end{array}$ & 43 & 20.8 \\
\hline Don't know & 22 & 10.6 \\
\hline Total & $\mathbf{2 0 7}$ & $\mathbf{1 0 0}$ \\
\hline
\end{tabular}

Table shows that the majority of respondents (152 or $73.4 \%)$ opined that leadership at the local government level is not as yet giving adequate attention and commitment to public education on climate change.

Research Question 6: What measures could be taken to enhance knowledge and understanding of climate change among residents of Awka South L.G.A? The findings are shown in Table 8 below.

Table 8: Distribution of Respondents by their view on how knowledge of climate change could be enhanced and made available to all

\begin{tabular}{|l|l|l|}
\hline Responses & Frequency & Percentage \\
\hline Public awareness campaign & 50 & $24.2 \%$ \\
\hline Involvement of non-governmental agencies & 28 & $13.5 \%$ \\
\hline $\begin{array}{l}\text { Use of traditional and modern mass media } \\
\text { structures }\end{array}$ & 103 & $49.8 \%$ \\
\hline $\begin{array}{l}\text { Use of traditional socio-political institutions to } \\
\text { spread information }\end{array}$ & 26 & $12.6 \%$ \\
\hline Total & $\mathbf{2 0 7}$ & $\mathbf{1 0 0 \%}$ \\
\hline
\end{tabular}

Table 8 shows that $50(24.2 \%)$ respondents suggested public awareness campaign as a mean to enhance knowledge of climate change among the people, $103(49.8 \%)$ of them advocated the use of traditional and modern mass media outfits, $26(12.6 \%)$ of them suggested use of traditional institutions to spread information. Similarly, respondents to the qualitative instrument recommended public awareness campaigns through mass media, seminars, workshops and road shows. It was also suggested that government should introduce study of climate change in the primary and secondary schools' curricula. 


\section{Test of Hypotheses}

The two hypotheses put forward for this study were tested and details are as shown below.

Hypothesis 1: There is a significant relationship between level of educational attainment and knowledge of climate change. Data in Table 9 formed the basis for testing hypothesis 1 .

Table 9: Relationship between Level of Educational Attainment and Selfassessment of how informed or Knowledgeable about Climate Change among residents of Awka South Local Government Area

\begin{tabular}{|c|c|c|c|c|c|}
\hline \multirow{2}{*}{$\begin{array}{l}\text { Highest level of } \\
\text { educational } \\
\text { attainment }\end{array}$} & \multicolumn{4}{|c|}{$\begin{array}{l}\text { Self-assessment of how informed or } \\
\text { knowledgeable about climate change }\end{array}$} & Statistics \\
\hline & $\begin{array}{l}\text { Well } \\
\text { informed }\end{array}$ & $\begin{array}{l}\text { Fairly } \\
\text { informed }\end{array}$ & $\begin{array}{l}\text { Not } \\
\text { informed }\end{array}$ & Total & \multirow{7}{*}{$\begin{array}{l}\mathrm{X} 2(10, \\
\mathrm{N}=203)= \\
41.949 \\
\mathrm{P}<0.001\end{array}$} \\
\hline FSLC & 1 & 15 & 16 & 32 & \\
\hline WAEC/NECO/SSCE & 19 & 53 & 13 & 85 & \\
\hline NCE/OND & 9 & 9 & 3 & 21 & \\
\hline B.SC/HND & 25 & 33 & 4 & 62 & \\
\hline PH.D & 5 & 1 & 1 & 7 & \\
\hline TOTAL & 59 & 111 & 37 & 207 & \\
\hline
\end{tabular}

The computed value of chi-square is 41.949 while the table value of chi square at 0.05 level of significance with a degree of freedom of 10 is 18.307 . Since the computed chi square value is greater than the critical value, the alternate hypothesis is accepted. It follows therefore that there is a significant relationship between level of educational attainment and self-assessment of knowledge of climate change in Awka South Local Government area among residents.

Hypothesis 2: There is significant relationship between occupation and perception of the socio-economic effects of climate change in Awka South Local Government area. Data in Table 10 formed the basis for testing hypothesis 2 . 
Table 10: Relationship between Occupation and Perception of SocioEconomic Effects of Climate Change in Awka Local Government Area

\begin{tabular}{|c|c|c|c|c|c|c|}
\hline \multirow[t]{2}{*}{$\begin{array}{l}\text { What is your } \\
\text { occupation }\end{array}$} & \multicolumn{4}{|c|}{$\begin{array}{l}\text { What is your perception of the socio-economic } \\
\text { effects of climate change in your area? }\end{array}$} & & Statistics \\
\hline & $\begin{array}{l}\text { Generates } \\
\text { poor farm } \\
\text { produce }\end{array}$ & $\begin{array}{l}\text { Loss of } \\
\text { life and } \\
\text { properties }\end{array}$ & $\begin{array}{l}\text { Health } \\
\text { problems }\end{array}$ & Insecurity & Total & \multirow{7}{*}{$\begin{array}{l}\mathrm{X} 2(10, \\
\mathrm{N}=204)= \\
26.669 \\
\mathrm{P}<0.085\end{array}$} \\
\hline Civil servant & 57 & 6 & 4 & 1 & 68 & \\
\hline Farmer & 12 & 1 & 1 & 1 & 15 & \\
\hline Trader & 40 & 3 & 4 & 1 & 48 & \\
\hline Student & 17 & 11 & 8 & 3 & 39 & \\
\hline Applicant & 25 & 5 & 6 & 1 & 37 & \\
\hline Total & 151 & 26 & 23 & 7 & 207 & \\
\hline
\end{tabular}

The computed value of chi square is 26.669 while the table value of chi square at 0.05 level of significant with a degree of freedom of 18 is 28.869 . Since the computed chi square value is less than the table value, the alternate hypothesis is rejected. It implies that there is no significant relationship between occupation and perception of socio-economic effects of climate change in Awka South local government area.

\section{Summary and Discussions of the Findings}

The study revealed that most people in Awka South L.G.A have heard or noticed climate change. They come to know of climate change through their social interaction with others, personal experiences and observations of the climate. It was further observed that intense heat, heavy and longer periods of rain resulting into flooding and delayed dry seasons (not coming when due) are the common manifestation of climate change in Awka south L.G.A. This finding is in agreement with Maddison (2006) who noted that the peoples' perception of climate change usually hinge on their experiences and information at their disposal with regard to climate and weather. Similarly, the indicators of climate change as outlined by IPCC (2007) align with the evidences of climate change in Awka South LGA as identified by study participants.

The study also revealed that residents of Awka South L.G.A are not very knowledgeable about climate change. Such skeletal information /knowledge at their disposal are also quite inaccurate and below scientifically proven facts. The majority of them see climate change as merely natural process or occurrence without interference from any other sources. The factor of human activities contributing to climate change was poorly recognized by respondents. This finding has implications for the need for residents to regulate their activities as a way to check climate change in their area. This is particularly important as IPCC (2007) argued that although climate change is a 
natural process, the greatest influence on the earth's climate is the activities of mankind which is a catalyst for the process of climate change. This finding is not in line with the findings of Agwu and Okhimamhe (2009) which attributes climate change to calamities inflicted by God.

Furthermore, this study found that the people in Awka South L.G.A perceive the impacts of climate change on their socio-economic activities more in the agricultural sector was in terms of poor farm produce as a result of erosion, flooding and heavy rain and dry seasons not coming when due. Also, destruction of life and properties, increased health problems and insecurity were probably perceived as minor climate change induced effects, hence they were lowly subscribed to by respondents in the area. This finding is in line with Agwu and Okhimamhe (2009) in their submission that south eastern Nigeria witnesses destruction of shelter (both human and animal), arable farmlands, access road and economic trees by landslides, erosions, flooding and tornados (arising from climate change). The perception that harsh socio-economic effects arise from climate change as found in the study area is further explained by the submission of IPCC (2007) that impacts of climate change would be globally felt but mostly by less developed societies that lack the infrastructures to cushion such impacts. The study area is one of such less developed societies.

The study found that occupation of the people does not influence their perception of the socio-economic effects of climate change. This implies that the effect of climate change is not occupation specific rather it touches all sectors of the society However, the level of educational attainment affected self-assessment of knowledge of climate change possessed by respondents.

It is noteworthy that study participants recommended vigorous public awareness campaign via traditional and modern mass media structures to bring information on climate change closer to the people. They also wanted government, non-governmental organizations, and the traditional institutions to be involved in the spread of information about climate change issues to the people. The importance of such views could be appreciated from the position of IPCC (2007) that mass education of the people in developing countries on climate change is the only way to cushion the effects of climate change that is already here. It went further to argue that traditional institutions are better placed to reach out to the rural dwellers who are the most vulnerable group.

Finally, the findings of this study amplify the view of Folami and Karimn (2010) that people's perception and knowledge of climate change influences their actions and decisions. This is because the low level of positive response to issues of climate change in the area of study is related to the nature perception and available knowledge about the phenomenon in the area.

\section{Conclusions and Recommendations}

Knowledge of climate change is very pertinent as drastic changes in the climate conditions have induced tremendous effects on the society. Climate change which has become one of the major global debates is yet to attract the deserved attention in Awka South L.G.A. The knowledge and perception of residents 
about the phenomenon remains a huge departure from reality. The people are poorly informed or knowledgeable about climate change. Also, socioeconomic effects of the phenomenon were also perceived to be heavy particularly in the agricultural sector. Unfortunately, the role of leadership/governance in addressing issues related to climate change is largely at its infancy with weak commitment. In view of the fact that people's perception and knowledge of climate change influences their actions and decisions towards it, there is immense need for proactive measures to be in place to control and prevent deleterious effects of climate change. Indeed, proper recognition of the role of knowledge and perception of climate change cannot be overemphasized taking cognizance of the fact that climate change is mostly anthropogenic that is an outcome of human activities. If people are therefore well informed about this, their environment and climatic conditions will be better off. To achieve such optimum climatic and environmental conditions suitable for sustainable socio-economic development of society, the following recommendations derived from our findings are put forward:

1. Traditional institutions should be empowered with proper knowledge of climate change and engaged in the dissemination of information especially among rural dwellers.

2. Non-governmental organizations should be involved who should organize seminars, workshops and road shows to inform and educate the people on dangers associated with climate change.

3. The government on their own part should embark on a massive public enlightenment campaign through the media to spread the message of climate change to the door step of the people.

4. Climate change studies should be part of general studies in higher institutions in the area. This will consolidate or boost gains from massive public enlightenment required to improve perception and knowledge of climate change in Awka South local government area of Anambra state of Nigeria.

5. In view of high level of education in the study area as evident from findings, and the surprisingly low level of knowledge of climate change among study participants, there is immense need to enrich the curricula of primary and secondary school geography and social studies with current issues, such as features, causes, prevention and control of climate change in society. This approach will facilitate proper understanding of climate change by school children who will also transmit such messages home.

\section{References}

Agwu, J. \& Okhimamhe, A.A. 2009. Gender and Climate Change in Nigeria. www.bollnigeria.org. assessed 23/8/14.

Arms, K. 1990. Environmental Science. Sander: Florida 
Blast, J.I. 2010. Seven Theories of Climate Change. Heartland Institute: Chicago.

Enger, E.D. \& Smith, B.F. 2002. Environmental Science: A Study o $f$ Inter Relationships. ( $8^{\text {th }}$ ed.). New York: McGraw Hill.

Environmental Resources Management Report. 2009. Impact of Climate Change on Nigeria's Economy. www.erm.com, assessed 13/7/14.

Giddens, A. 2006. Sociology. ( $5^{\text {th }}$ ed.). Polite: London.

Haralambos, M. \& Holborn, M. 2008. Sociology: Themes and Perspective. $\left(7^{\text {th }}\right.$ ed.). London: Harper Collins.

Fellmam, J.D. 2002. Human Geography. ( $7^{\text {th }}$ ed.). New York: McGraw Hill.

Folami, A.O. \& Karimn, O.O. 2010. Climate Change and Border Crime in Nigeria. www.climsec.prio.no/paper/assessed 7/9/14.

Federal Ministry of Environment. 2003. www.unced.int, assessed 2/10/14.

Intergovernmental Panel on Climate Change (IPCC) Report. 2001. www.grida.no.

Intergovernmental Panel on Climate Change (IPCC) Report 2007. www.ipcc.ch.

London Climate Change Partnership Report. 2002. London's Warming: The Impacts of Climate Change on London. London: Polite.

Leisermitz, A. 2003. Climate Change Risk Perception and Publicity preference: The Role of Affect, Imagery and Values. New York: Harper Collins.

Maddison, D. 2006. The Perception and Adaptation to Climate Change. www.freelibrary.com assessed 21/10/14.

Makofake, W.J. \& Karlin, E.F. 1995. Technology and Global Environmental Issues. New York: HarperCollins.

Nigeria Environmental Study Team Report. 2003. Climate Change in Nigeria. Ibadan: NEST.

Nnoyelu, Au. 2006. Sociological Insight. Ibadan: Spectrum.

Odjugo, P.O. 2010. General Overview of Climate in Nigeria. Journal of Geography and Regional Planning. 3: 6.

Odjugo, P.O. 2010b. Regional Evidence of Climate Change in Nigeria. Journal of Human Ecology. 29: 1.

Tietenberg, T. 2003. Environmental and Natural Resource Economic. ( $6^{\text {th }}$ ed.). New Delhi: Pearson.

Wikipedia. 2010. http://en.m.wikipedia.org/wiki/awka-south.

Wikipedia. 2010. http://en.m.wikipedia.org/wiki/socialrepresation Theory. 